\title{
Solution for Sustainable Development for Developing Countries: Waste Water Treatment by Use of Membranes - A Review
}

\section{Ashutosh Kumar Pandey ${ }^{1 *}$, Brijesh Singh ${ }^{1}$, Sudha Upadhyay ${ }^{2}$, Srinath Pandey ${ }^{3}$, Ved Kumar Mishra ${ }^{3}$ and Prashant Ankur Jain ${ }^{4}$}

${ }^{1}$ Department of Biochemical Engineering, Harcourt Butler Technical University (HBTU), Kanpur- 208002, India

${ }^{2}$ Chemical Engineering, Dr. Ambedkar Institute of Technology for Handicapped, [Affiliated to Dr A P J Abdul Kalam Technical University (AKTU Code-429), Lucknow, Uttar Pradesh, Kanpur-208024, India

${ }^{3}$ Department of Biotechnology, Naraina Vidya Peeth Engineering and Management Institute, [Affiliated to Dr A P J Abdul Kalam Technical University (AKTU Code-429), Lucknow, Uttar Pradesh, India], Naraina Group of Institution, Gangaganj, Panki, Kanpur, Uttar Pradesh-208020, India

${ }^{4}$ Department of Computational Biology and Bioinformatics, Jacob School of Biotechnology and Bioengineering, Sam Higginbottom University of Agriculture, Technology and Sciences (SHUATS), Allahabad, U.P.-211007, India

*Corresponding author

\begin{tabular}{|c|c|}
\hline & B S T R A $\mathbf{C}$ \\
\hline & \multirow{6}{*}{$\begin{array}{l}\text { In developing countries, industrialization is the main cause of water pollution because of } \\
\text { the various industries which generate wastewater that is needed to be discharged. The } \\
\text { availability of fresh clean water is becoming increasingly limited in many areas of the } \\
\text { world resulting in scarcity of potable water in many regions around the globe. The } \\
\text { membranes have emerged as an efficient compact technology for municipal and } \\
\text { industrial wastewater treatment. The separation and retention of biological solids has been } \\
\text { widely applied as one of the alternatives to the conventional activated sludge process. The } \\
\text { absolute retention of all microorganisms by membranes makes it possible to treat } \\
\text { wastewater effectively. The membrane bioreactor is responsible for the remaining } \\
\text { biochemical oxygen demand (BOD) removal, while the refractory matter (contributed to } \\
\text { COD) is removed. This paper provides an overview of membranes fouling and studies } \\
\text { conducted to identify mitigating strategies for fouling in Membrane bioreactors. Classes } \\
\text { of foulant, including biofouling, organic foulant, and inorganic fouls, as well as factors } \\
\text { influencing membranes fouling are outlined. Recent research attempts on fouling control, } \\
\text { including the addition of coagulants and adsorbents, a combination of aerobic granulation } \\
\text { with Quorum quenching also offers a strong potential for fouling control, but pilot-scale } \\
\text { testing is required to explore the feasibility of full-scale application. }\end{array}$} \\
\hline Keywords & \\
\hline $\begin{array}{l}\text { Membrane, } \\
\text { Wastewater, } \\
\text { Fouling. }\end{array}$ & \\
\hline Article Info & \\
\hline $\begin{array}{l}\text { Accepted: } \\
17 \text { June } 2017 \\
\text { Available Online: } \\
10 \text { August } 2017\end{array}$ & \\
\hline & \\
\hline
\end{tabular}

\section{Introduction}

Expansion of population in developed and developing countries cause the scarcity of pure water and pollute it by releasing waste water into the rivers and ponds. In developing 
countries, industrialization is the main cause of water pollution because of the various industries which generate wastewater that is needed to be discharged. Recycling is the best policy for regaining the fresh and potable water. Technology came into consideration since the gradual banning of waste water discharge into the natural resources of water, primarily the river.

Application of membranes technology to wastewater treatment has expanded over the last decades due to increasingly stringent legislation and continuing advancement of membranes technology. In particular, the membrane bioreactor (MBR) systems for the separation and retention of biological solids have been widely applied as one of the alternatives to the conventional processes. The absolute retention of all microorganisms by membranes makes it possible to treat wastewater effectively. In addition, membranes technology has been used for a tertiary wastewater treatment process. After secondary biological wastewater treatment, a membranes filtration of secondary effluents has been applied for an advanced wastewater treatment regime [1].

The rapid expansion of the population in developing countries caused the overloading of existing conventional wastewater treatment plants and there will be no space available for expansion of the existing treatment plant [3].

In view of this, MBR has attracted growing interests as it has some distinct advantages of smaller footprint, less sludge production, higher separation efficiency and highly improved effluent quality as compared to conventional activated sludge treatment $[4,5]$. MBR is also able to retain small molecular weight organic micropollutants compared to conventional activated sludge process. MBR with ultrafiltration membranes is also able to retain some types of viruses [6].
The MBR market is growing faster and has contributed to the larger market for wastewater treatment equipment including physical treatment, chemical treatment, biological treatment and membranes filtration. The membrane processes for municipal and industrial applications cover the pretreatment, MBR configuration, membranes fouling, fixed film and anaerobic MBR, membranes technology advances and modeling [7]. Most review articles related to integrated MBR are anaerobic MBR (AnMBR) which has the advantage of reducing organic matter and producing energy under anaerobic processes [8].

[9] investigated the integrated MBR-photo electro oxidation (MBR-PEO) for tannery wastewater treatment. The MBR is responsible for the remaining biochemical oxygen demand (BOD) removal, while the refractory matter (contributed to COD) is removed by PEO. The treated wastewater could be recycled for the tanning and retanning steps. The principal limitation of both processes lies in membranes fouling which is mainly associated with the deposition of a biosolids cake layer onto the membranes surface, thus limiting the permeate flux [2].

\section{Membranes}

Membranes technology has made the recycling of waste water a realistic possibility. MBR is able to retain small molecular weight organic micropollutants compared to conventional activated sludge process. MBR with Microfiltration, Ultrafiltration, Nanofiltration and Reverse Osmosis (RO) membranes is also able to retain some type viruses, organic and inorganic compounds.

The membranes are a barrier that control the transmission of different chemical compounds and separates two phases. The two phases in a membrane process are physically separated 
from each other by a third phase. One of the mixture components is transferred more than the other that is feed, the membranes selectivity to one of the component is responsible for the transition of that component from one phase into another.

The Membranes Selectivity

$\mathrm{R}=(1-\mathrm{Cp}) / \mathrm{Cr}$

$\mathrm{Cp}=$ Concentration of the Components in the permeate flow.

$\mathrm{Cr}=$ Concentration of the Components in the non-passed flow through the membranes.

\section{Membranes process}

\section{Microfiltration}

It is a filtration process in which porous membrane is used for the separation of suspension particle with different size variation 0.08 to $2.0 \mu \mathrm{m}$. Retained compounds are very small suspended particles, some colloids and most bacteria.

Operating pressure: 1 to 15 psi.

Temperature: $80^{\circ} \mathrm{F}\left(27^{\circ} \mathrm{C}\right)$.

\section{Ultrafiltration}

It is known as a process between microfiltration and nano filtration. In ultrafiltration, range of pores varies from 0.005 to $0.2 \mu \mathrm{m}$.

With smaller pore size, the larger particles pass less through the membranes.

The rate of filtration depends on the pore size of the membranes.

It is also capable of disposing a particle in the molecular weight range of 300 to 500000 .
Retained compounds are organics > 1000 molecular weight pyrogens, viruses, bacteria and colloids are separated.

Operating pressure: 10 to 100 psi.

Temperature: $80^{\circ} \mathrm{F}(27)^{\circ} \mathrm{C}$.

Recovery rate: $75 \%$ recovered from feed water.

\section{Nano Filtration}

It lies between the ultrafiltration and reverse osmosis process, the membranes used in Nano filtration contain pore closer to nano level or to lower than nanometer. Size is usually around 0.001 to $0.01 \mu \mathrm{m}$.

Retained compound from Nano filtration is organic >300 molecular weight.

Operating pressure: 80 to 125 psi.

\section{Reverse osmosis}

It refers to a process in which the minerals are separated from water by membranes permeable to water and impermeable to minerals. The water containing minerals enter into the membranes by applying pressure from the feeding side and the solute free water is collected as the leaked flow.

Product particle size: 0.0001 to $0.001 \mu \mathrm{m}$.

Retained compound, ions, organic compound $>100$ molecular weight

Operating pressure: 125 to $1000 \mathrm{psi}$.

\section{Electrodialysis}

The ED system consists of ion exchange membranes arranged between cation and anion. Ionic compounds in the feed water start 
to move across ion exchange membrane using an electrical driving force. The cations in the solution migrate towards the cathode and the anions migrate toward the anode due to electrical current between the two. Cations pass through the cation exchange membrane and are retained by the anion exchange membrane.

Similarly, anions pass through the anion exchange membrane and are retained by the cation exchange membrane. The overall result of the process is that a concentrated and diluted compartment occurs in the system. The electrolyte solution ensures the conductivity and removes gases produced by electrode reactions in the system.

\section{MBR as a sustainable wastewater treatment option}

Membrane bioreactors utilize activated sludge process which supersedes gravity settling of conventional ASP and makes use of microfiltration $(0.1$ to $10 \mu \mathrm{m})$ or ultrafiltration $(0.01$ to $0.1 \mu \mathrm{m})$ membranes as a physical barrier for the final clarification. It is a process that uses both a biological stage and a membrane module for wastewater treatment.

Membranes use for separation of solids and treated wastewater is the main difference between Membrane bioreactors and traditional treatment plants for which the efficiency of the final clarification step depends mainly on the activated sludge settling properties [10]. Membranes bioreactors could be developed for both attached growth and suspended growth processes. Moreover, Hybrid Membrane bioreactors are also developed in recent years. There are two basic configurations of Membrane Bioreactors based on the location of membrane components with respect to bioreactor basin.

\section{Cross-Flow MBR (Also Referred as Side} Stream or External Membranes MBR)

In this type, membrane component is placed in a separate vessel, outside the bioreactor basin. In CF-MBR, usually polymeric flat sheet membranes are used and the mixed liquor is filtered under pressure in a specific outer skin membrane module. The permeate flux varies between $50-120 \mathrm{~m}^{3} / \mathrm{m}^{2} / \mathrm{s}$ and the Trans Membrane Pressure (TMP) ranges from 1 to 4 bar [10].

\section{Submerged (or immersed) MBR}

In this type, membranes component is immersed inside the bioreactor basin. Usually hollow fiber membranes are used for submerged Membrane bioreactors. For the submerged configuration, the filtration is carried out in the aeration basin by suction removal of the effluent. The permeate flux varies from 15 to $50 \mathrm{~m} 3 / \mathrm{m} 2 / \mathrm{s}$ and the TMP is about 0.5 bar [10].

\section{Applications of MBR technology in wastewater treatment}

The Membrane Biological Reactor (MBR) configuration optimizes the process of industrial waste water treatment when treatment efficiency is an important factor [11]. It has a wide range of applications including municipal, industrial wastewater treatment and solid waste digestion. Major industrial wastewater sources include food processing, pulp and paper, textile, chemical, pharmaceutical, petroleum, tannery, and manufacturing industries.

Industrial applications of MBR was investigated for a commercial laundry and a textile factory in Germany by Jan Hoinkis et $a l ., 2012$ and they resulted that despite having a high concentration of low biodegradable chemical in wastewater, the COD removal 
efficiency achieved around 90\% [12]. Moreover, It has been reviewed that MBR treatment systems can reduce BOD greater than $98 \%$; reduce COD up to $98 \%$; produce a consistent $\mathrm{NH}^{+}$removal rate up to $99 \%$, provide 5-log removal of E. coli; and eliminate greater than $97 \%$ phosphorus. ammonia as $\mathrm{NH}_{4}{ }^{+}$in wastewater found to be completely converted into $\mathrm{NO}_{3}^{-}$ions as compared to a conversion rate of $95 \%$ for conventional activated sludge processes. Tables 1 and 2 present overviews of MBR applications in the industrial wastewater treatment area.

\section{Water demand in India}

India is the seventh largest country in the world with more than 1.2 billion inhabitants. Apparently, such a huge population places a strong burden on all of its natural resources especially its water, most of which is contaminated by sources such as sewage, agricultural runoff, and industrial chemicals. The average availability of potable water in India is constantly reduced with the increasing population, fast economic growth, and industrialization, and it is expected to become a water stressed nation in the near future.

Although access to potable water has improved, 75 percent of India's rural population still does not have access to clean and safe drinking water and more than 80 percent of diseases and 33 percent of deaths are caused primarily by contaminated drinking water [13]. The worst affected Indian regions are Rajasthan, Karnataka, and Gujarat, where more than 40 million people have been suffering from fluorosis due to the high amount of fluoride. In West Bengal, many people are suffering from arsenicosis because of the high level of arsenic. Considering the current status of the available water in India, it creates various opportunities for companies to enter the water filtration market [14]. In order to counter this issue, the Indian government budgeted around USD $\$ 26.5$ billion in the period 2012-2017 for providing potable water to all rural and urban Indians. Thus, treatment of wastewater, solid, chemical and liquid waste, and sewage treatment and desalination of water are necessary services that India will require to solve its upcoming water deficit [15].

\section{Membranes technologies on the Indian water purification market}

\section{Market developments and characteristics}

In India, in addition to desalination and wastewater treatment, membrane technologies hold great potential for water purification. This is especially in case with households due to the fact that many of them, especially in rural areas, have often no or limited access to municipal water and are thus forced to treat their own water. In the recent years, the Indian water purifier market has experienced vast growth opportunities. According to Research Gate, it is expected to grow around 25 percent until 2017 and worth some US\$ 760 million by the end of 2015 [16]. One of the main reasons for this tremendous growth rate and development is rising product consciousness across rural and urban markets. The major water sources in the states like Rajasthan, West Bengal, Bihar, Orissa, Andhra Pradesh, and Tamil Nadu still have a high metal content and thus the demand for water purifiers. Until recently, the water purifier companies have not taken notice of the rural markets due to the low-income level, weak distribution networks and sales of the manufacturers and companies in these areas. However, many global players and local companies are now penetrating the Indian rural market with innovative low-price and low-cost products, especially the offline water purifier industry [17]. 


\section{Technology trends, gaps and opportunities}

India's water purifier market is dominated by small technologies for households, which are mainly based on the reverse osmosis design for filtration of fresh water. Water purifiers for households are mainly sold in outlet stores, while approximately 30 percent of UV + RO-based water purifiers are sold via the 'direct to home' channel. Therefore, many well established key players set up their own exclusive branded water purifier outlets [18]. Modern as well as existing companies, are focusing mainly on membranes based especially RO based- water purifiers, which is also the fastest growing application in the Indian water purifier market.

\section{Membranes technologies on the Indian wastewater treatment market}

\section{Market developments and characteristics}

Although government support and private participation accelerated the growth of the wastewater treatment sector in India in the last decade, the need for improvement remains tremendous. It is estimated that only about 20 percent of domestically generated sewage and 60 percent of industrially generated wastewater is treated [19]. Furthermore, large cities treat around 29 percent and small cities only 3.7 percent of their wastewater. Currently, there are more than 230 sewage water treatment plants. Most of these plants in India were developed under various governmental river action plans and are located in cities along the banks of major rivers, according to a CPCB report.

\section{Technology trends, gaps and opportunities}

In comparison to Europe, in the majority of the Indian tier I cities, activated sludge or oxidation pond processes and chlorination is the most commonly used technologies covering around 59.5 percent of total installed capacity. This is followed by up-flow anaerobic sludge blanket technology, which covers around 26 percent of total installed capacity. Moreover, waste stabilization pond technology is also installed in many wastewater treatment plants [20].

The trend is evolving to the greater use of membrane technologies that enhance the quality of water available for reuse and which already have a wide presence in Europe. Therefore, there is a strong potential for European companies to replace conventional methods in India, especially the chlorination process. This new generation of wastewater treatment technologies is able to treat the industrial and domestic sewage similar to the quality of river water. However, the costs of maintaining and implementing activated sludge processes, which are currently used in many industries and municipalities, are far lower than MBR [21]. Therefore, alternative cost effective solutions for water applications, for example, nanotechnologies like nonporous polymers, Nanomembranes, forward osmosis and membranes distillation could hold even higher potential for the Indian market.

\section{Developments of membranes/filters}

\section{Key players}

$\begin{array}{ll}\text { Company } & \text { Country } \\ \text { Veolia } & \text { France } \\ \text { Accionia } & \text { Spain } \\ \text { Befesa Agua } & \text { Spain } \\ \text { Biwater } & \text { UK } \\ \text { Suez } & \text { France } \\ \text { FisiaItlimpianti } & \text { Italy }\end{array}$

Recent progress in thin film composite membranes

Thin Film Composite (TFC) membranes have experienced exceptional development since 
the concept of Interfacial Polymerization (IP) was first introduced by Mogan in 1965 [44]. It is generally acknowledged that the scientific breakthrough in developing ultrathin film onto a microporous substrate is equivalent to the historic announcement of LoebSourirajan asymmetric membranes in 1960. Owing to ultrathin selective layer, Reverse Osmosis (RO) and Nanofiltration (NF) membranes prepared using this coating technique have emerged as excellent candidates in a wide variety of separation applications, particularly in the water and wastewater treatment processes $[45,46]$.

TFC membranes have been well received in industrial use, there is still an interest among membrane scientists in developing asymmetric membranes via single-step fabrication process [47, 48]. It is generally agreed that asymmetric membranes can tolerate the fairly high level of feed water chlorine in comparison to composite membranes prepared from polyamide (PA) [49].

Several key advantages of TFC membranes, however, have kept them much competitive in the commercial market. It must be mentioned that each layer (i.e. top selective layer and bottom porous substrate) of TFC membranes can be independently controlled and optimized to achieve desired selectivity and permeability while offering excellent mechanical strength and compression resistance. Apart from IP technique, coating techniques such as photo-grafting, dipcoating, electron beam irradiations and plasma-initiated polymerization are also introduced to apply an ultrathin barrier layer upon support membranes. Interfacial polymerization is of particular interest in composite membranes preparation by taking into account a considerable amount of research work that has been conducted so far $[50,51]$.

\section{Influence of membranes characteristics on MBR performance}

Membrane characteristics such as pore size, porosity, surface charge, roughness, and hydrophilicity/hydrophobicity, etc., have been proven to impact on MBR performance, especially on membranes fouling.

The determination of suitable membrane pore sizes has been extensively investigated in the 1990s. Due to different pore size, morphology, and hydrophobicity, the membranes material always shows different fouling property. Polyvinylidene fluoride (PVDF) membranes are superior to polyethylene (PE) membranes in terms of prevention of irremovable fouling in Membrane bioreactors used for the treatment of municipal wastewater [42].

Regarding MBR processes, the fouling behavior of the membranes used is determined by the affinity between foulant (e.g., EPS/SMP) and membranes. [43] studied the affinity between EPS and three polymeric ultrafiltration membranes, and observed that the affinity capability of the three membranes was of the order: PAN < PVDF < PES. According to these PAN membranes has more fouling-resistant.

\section{Past and present scenario}

\section{Evolution of MBR technology}

The first MBR installation (Membranes Sewage System-MST) commercialized in the $70^{\prime} \mathrm{s}$ and $80^{\prime} \mathrm{s}$ was based on side stream configurations, made by Dorr-Oliver, Inc., with flat sheet ultrafiltration plate operated at excessive pressure (3.5 bar inlet pressure) and low flux rate $(17 \mathrm{l} /(\mathrm{m} 2 \mathrm{~h}))$, yielding mean permeability [52]. However, installation of the first large full-scale MBR system for industrial wastewater treatment was at the 
General Motors plant in Mansfield, Ohio (U.S.) in the early 1990s [53].

\section{Present scenario and market status}

Hollow fiber MBR system is one of the early stage distinguished techniques that are still expected to dominate the market globally over the coming years. Simplicity and high output efficiency have helped hollow fiber MBR systems sustain relentlessly over the past couple of years. Flat sheet and Multitubular products provoke high operation and maintenance costs which led to their dampened market growth. MBR systems market was dominated in 2012 by submerged systems that are likely to continue over the predicted period.

High operation and maintenance cost has dampened the side stream configuration segment growth. The most cited market analysis report indicates a compound annual growth rate (CAGR) of $13.2 \%$ and predicts a global market value of \$ 627 million in 2015 (BCC, 2011). This growth rate is much higher than the other wastewater treatment technologies. Further, the market is expected to increase twice over the present growth rate in the next five years.

\section{Future trends}

Many studies have been conducted and much progress has been achieved in optimizing membrane characteristics and performance. Some factors include: membrane characteristics (material type, water affinity, surface roughness, surface charge, and pore size), operating conditions (operating mode, rate of aeration, SRT, HRT, F/M ratio, OLR, $\mathrm{COD} / \mathrm{N}$ ratio, and temperature), and feed and biomass characteristics (MLSS, sludge apparent viscosity, EPS, floc size, alkalinity, $\mathrm{pH}$ and salinity). However, some challenges still need to be addressed, such as decreasing membrane fouling; increasing the membrane lifetime, selectivity, and permeability; improving thermal, mechanical, and chemical resistance; and reducing energy consumption. One of the most crucial problems facing the world in this century is the provision of clean water with adequate quality from water resources. Given the numerous privileges of membranes such as relatively high selectivity and permeability, low energy consumption, operational simplicity, control, scale-up, and adaptability, as well a satisfactory stability under various conditions, over the years membranes have been the dominant technology in the water treatment industry.

Fig.1 Mechanism of membranes fouling in MBR

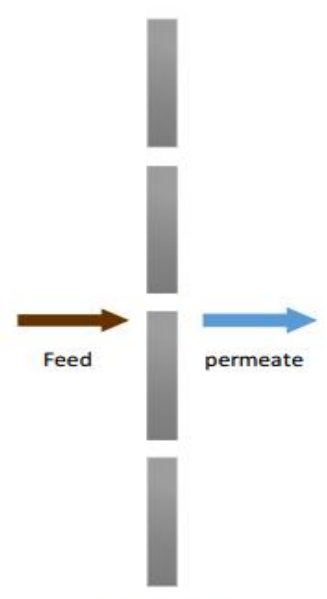

(a) New membrane

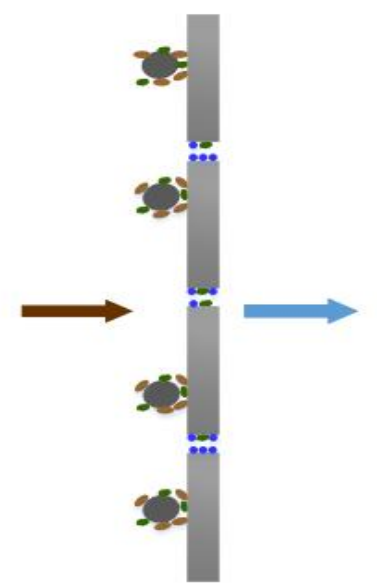

(b) Pore narrowing

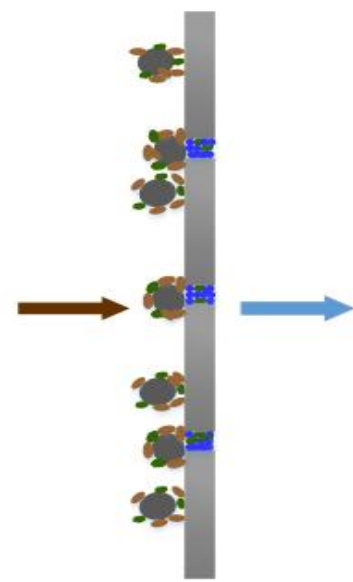

(c) Pore clogging

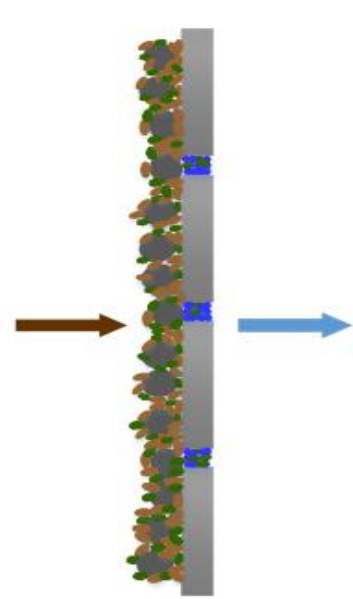

(d) Cake formation 
Fig.2 Classification of membranes fouling

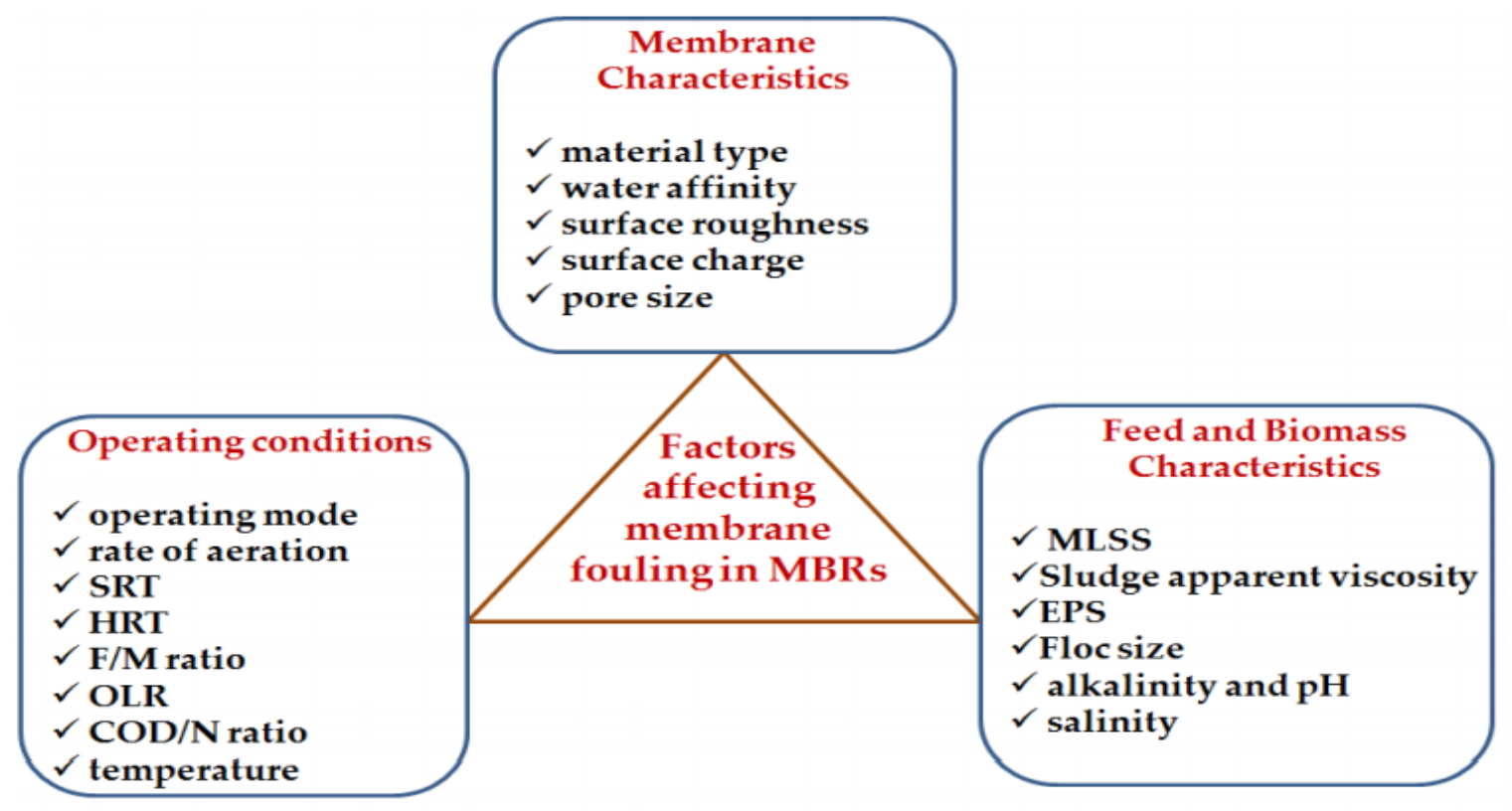

Table.1 Comparative analysis of cross-flow MBR and submerged MBR

\begin{tabular}{|c|c|c|c|}
\hline $\begin{array}{l}\text { S. } \\
\text { No. }\end{array}$ & $\begin{array}{l}\text { Comparative } \\
\text { factor }\end{array}$ & Cross- flow MBR & Submerged MBR \\
\hline 1. & $\begin{array}{l}\text { Membranes } \\
\text { area } \\
\text { Requirement }\end{array}$ & $\begin{array}{l}\text { Characterized by higher flux }(5-100 \\
\left.\mathrm{m}^{3} / \mathrm{m}^{2} / \mathrm{sec}\right) . \text { This lower membrane is } \\
\text { required. }\end{array}$ & $\begin{array}{l}\text { Lower flux }\left(15-35 \mathrm{~m}^{3} / \mathrm{m}^{2} / \mathrm{sec}\right) \text { but higher membranes } \\
\text { packing density. (i.e. membranes area per unit volume). }\end{array}$ \\
\hline 2. & $\begin{array}{l}\text { Space or } \\
\text { footprint } \\
\text { Requirement }\end{array}$ & $\begin{array}{l}\text { Higher flux membranes with bioreactor } \\
\text { operating at higher VSS concentration and } \\
\text { skidded assembly construction. Result in } \\
\text { compact system. }\end{array}$ & $\begin{array}{l}\text { Higher membranes packaging density and operation at } \\
\text { bioreactor VSS conc. of } 10 \mathrm{~g} / \mathrm{l} \text { or greater translate to } \\
\text { compact system. }\end{array}$ \\
\hline 3. & $\begin{array}{l}\text { Membranes } \\
\text { performance } \\
\text { consistency }\end{array}$ & $\begin{array}{l}\text { Less susceptible to changing waste water } \\
\text { and biomass characteristics. }\end{array}$ & $\begin{array}{l}\text { More susceptible to changing waste water and biomass } \\
\text { characteristics requiring alteration in membranes } \\
\text { cleaning strategy and /or cleaning frequency. }\end{array}$ \\
\hline 4. & $\begin{array}{l}\text { Recovery of } \\
\text { membranes } \\
\text { performance }\end{array}$ & $\begin{array}{l}\text { Offline cleaning required every } 1-2 \text { months. } \\
\text { Simple automate procedure normally } \\
\text { requiring less than } 4 \text { hour. }\end{array}$ & $\begin{array}{l}\text { Offline recovery cleaning. Cleaning required every 2- } \\
6 \text { months., a more complex procedure requiring } \\
\text { significantly more time and manual activity at least on } \\
\text { occasion maybe required. }\end{array}$ \\
\hline 5. & $\begin{array}{l}\text { Membranes } \\
\text { life or } \\
\text { Replacement } \\
\text { requirement }\end{array}$ & $\begin{array}{l}\text { An operating life of } 7 \text { year or more can be } \\
\text { achieved with polymeric prior to } \\
\text { irreversible falling. Operating life of } \\
\text { ceramic is much longer. }\end{array}$ & $\begin{array}{l}\text { An operating life of } 5 \text { year maybe possible prior to } \\
\text { irreversible fouling and /or excessive membranes } \\
\text { physical damage. }\end{array}$ \\
\hline 6. & Economics & $\begin{array}{l}\text { Non- conventional designs translate to } \\
\text { comparable power cost, Comparable capital } \\
\text { cost at least at lower wastewater feed rate, } \\
\text { higher OPEX and lower CAPEX, aeration } \\
\text { cost low (nearly } 20 \% \text { of OPEX) and high } \\
\text { pumping cost } 60-80 \% \text { of OPEX. }\end{array}$ & $\begin{array}{l}\text { Power and capital cost advantage at higher waste water } \\
\text { feed rate appears to be more economical based on energy } \\
\text { consumption., lower OPEX and higher CAPEX, aeration } \\
\text { cost high nearly } 90 \% \text { of OPEX and very low liquid } \\
\text { pumping cost, higher if suction pump is used nearly } 28 \% \\
\text { of OPEX. }\end{array}$ \\
\hline 7. & $\begin{array}{l}\text { Type of } \\
\text { energy } \\
\text { requirement }\end{array}$ & 2 to $10 \mathrm{KW} \cdot \mathrm{h} / \mathrm{m}^{3}$ & 0.2 to $0.04 \mathrm{KW} \mathrm{h} / \mathrm{m}^{3}$ \\
\hline
\end{tabular}


Table.2 Different sources of wastewater with different technologies of treatment

\begin{tabular}{|l|l|l|l|l|}
\hline $\begin{array}{l}\text { Waste water } \\
\text { sources }\end{array}$ & $\begin{array}{l}\text { Membranes } \\
\text { configuration }\end{array}$ & Size of operation & $\begin{array}{l}\text { Treatment } \\
\text { Efficiency }\end{array}$ & $\begin{array}{l}\text { Country } \\
\text { application }\end{array}$ \\
\hline Various sources & $\begin{array}{l}\text { Ultrafiltration- } \\
\text { external }\end{array}$ & $\begin{array}{l}\text { Pilot scale }(0.2- \\
\left.24.6 \mathrm{~m}^{3} / \mathrm{d}\right)\end{array}$ & $\begin{array}{l}\text { COD removal } \\
>97 \%\end{array}$ & GERMANY \\
\hline Paint industry & $\begin{array}{l}\text { Ultrafiltration- } \\
\text { external }\end{array}$ & Full scale $\left(113 \mathrm{~m}^{3} / \mathrm{d}\right)$ & $\begin{array}{l}\text { COD removal - } \\
>94 \%\end{array}$ & USA \\
\hline Tannery industry & $\begin{array}{l}\text { Ultrafiltration- } \\
\text { external }\end{array}$ & $\begin{array}{l}\text { Full scale }(500-600 \\
\left.\mathrm{m}^{3} / \mathrm{d}\right)\end{array}$ & $\begin{array}{l}\text { COD removal - } \\
>93 \%\end{array}$ & GERMANY \\
\hline Cosmetic industry & $\begin{array}{l}\text { Ultrafiltration- } \\
\text { external }\end{array}$ & Full scale & $\begin{array}{l}\text { COD removal - } \\
>98 \% ~\end{array}$ & FRANCE \\
\hline Food industry & Microfiltration & Full scale $\left(600 \mathrm{~m}^{3} / \mathrm{d}\right)$ & $\begin{array}{l}\text { COD removal - } \\
>97 \%\end{array}$ & USA \\
\hline Aerobic & Microfiltration & $\begin{array}{l}\text { Bench scale }(0.05- \\
\left.0.09 \mathrm{~m}^{3} / \mathrm{d}\right)\end{array}$ & $\begin{array}{l}\mathrm{COD} \text { removal }->68- \\
82 \%\end{array}$ & CANADA \\
\hline Electrical industry & $\begin{array}{l}\text { Ultrafiltration- } \\
\text { external }\end{array}$ & Full $\mathrm{scale}\left(10 \mathrm{~m}^{3} / \mathrm{d}\right)$ & $\begin{array}{l}\text { COD removal - } \\
>97 \% ~\end{array}$ & GERMANY \\
\hline
\end{tabular}

Membrane fouling in Membrane bioreactors can be classified into biofoulants, organic foulants and inorganic foulants based on their biological and chemical characteristics. Of these, biofoulants and organic foulants are the major contributors to membranes fouling in Membrane bioreactors. Most research on membranes fouling targets these foulants.

\section{Recent advances in membranes bioreactors (Membrane bioreactors)}

\section{Characteristics of membranes fouling and its importance in membrane bioreactors}

Membranes' fouling is a major problem in faster commercialization of Membrane bioreactors. Membranes fouling in Membrane bioreactors can be attributed to both membranes pore clogging and sludge cake deposition on membranes which is usually the predominant fouling component [22]. Membranes fouling results in a reduction of permeate flux or an increase of trans membrane pressure (TMP) depending on the operation mode. With respect to Membrane bioreactors, membranes fouling occurs due to the following mechanisms: (1) adsorption of solutes or colloids within/on membranes; (2) deposition of sludge flocks onto the membranes surface; (3) formation of a cake layer on the membranes surface; (4) detachment of foulant attributed mainly to shear forces; (5) the spatial and temporal changes of the foulant composition during the long-term operation (e.g., the change of bacteria community and biopolymer components in the cake layer). In other words, the membranes fouling can be defined as the undesirable deposition and accumulation of microorganisms, colloids, solutes, and cell debris within/on membranes. Given the complex nature of the activated sludge, it is not surprising that the fouling behavior in Membrane bioreactors is more complicated than that in most membranes applications.

\section{Classification of membranes fouling}

\section{Removable and irremovable fouling}

Particle sizes of sludge flocks, colloids, and solutes in mixed liquor may strongly affect fouling mechanisms in a membranes filtration system. If foulants are comparable with the membrane pores (i.e., colloids), or smaller than the membrane pores (i.e., solutes), adsorption on pore wall and pore blocking may occur. However, if foulants (i.e., sludge flocks and colloids) are much larger than the 
membranes pores, they tend to form a cake layer on the membranes surface. By now, the concepts of reversible fouling and irreversible fouling are confusing because of different definitions proposed in publications. Generally, the irreversible fouling should be defined as the fouling that cannot be removed by any methods including chemical cleaning. But, some previous studies defined the irreversible fouling as the fouling that can be removed by chemical cleaning but cannot be removed by physical cleaning. Here, we define three types of fouling: removable fouling, irremovable fouling, and irreversible fouling. The removable fouling can be easily eliminated by implementation of physical cleaning (e.g., backwashing) while the irremovable fouling needs chemical cleaning to be eliminated. The removable fouling and reversible fouling are the same. The removable fouling is caused by loosely attached foulant; however, irremovable fouling is caused by pore blocking and strongly attached foulant during filtration. The irreversible fouling is a permanent fouling which cannot be removed by any approaches. In general, removable fouling is attributed to the formation of the cake layer, and the irremovable fouling is attributed to pore blocking.

\section{Formation of the Cake Layer}

In many cases, cake layer formation linked with removable fouling was considered as the major contributor to membranes fouling in Membrane bioreactors. Lee et al., (2001) reported that the filtration resistances included membranes resistance $(12 \%)$, cake resistance (80\%), blocking and irremovable fouling resistance $(8 \%)$, indicating that the formation of cake layer is the main cause leading to membranes fouling. Recently, a large number of scientific investigations have been performed in order to gain a better understanding of cake layer formation and cake layer morphology. Ping Chu et al., (2005) reported that the cake layer was not uniformly distributed on the entire surface of all of the membrane fibers. The membranes were covered partially by a static sludge cake that could not be removed by the sheer force due to aeration, and partially by a thin sludge film that was frequently washed away by aeration turbulence. They also pointed out that the deposited biopolymers allow easier and faster bacterial adhesion. In addition, the EPS holds the flocs more tightly on the membranes and increases the difficulty of cake removal by aeration turbulence. Jeison and Lier (2007) performed a study on a labscale anaerobic submerged membranes bioreactor (AnMBR) for over 200 days, and observed that cake formation was removable on a short-term basis, however, cake consolidation was observed when a long-term operation was performed at a flux close to the critical flux. The consolidated cake could not be removed by the backflush cycles and required an external physical cleaning procedure. Di Bella et al., (2007) found that the cake in an aerobic MBR had a main removal nature. These investigations suggest that the cake layer formed with aerobic sludge and anaerobic sludge might have different removability.

\section{Irremovable fouling in membrane bioreactors}

Although most of the recent research activities are focused on the fundamental understanding of the cake layer, the investigation and control of irremovable membranes fouling are of great importance for the long-term and sustainable operation of Membrane bioreactors. During initial filtration, colloids, solutes, and microbial cells pass through and precipitate inside the membranes pores. But, during the long-term operation of Membrane bioreactors, the deposited cells multiply and yield EPS, which 
clog the pores and form a strongly attached fouling layer. At the same time, some inorganic substances might progressively precipitate onto the membranes or into the membranes pores. The occurrence of MBR fouling is a very complex process. Thus, how to predict and control fouling is of great significance for MBR operation. Operation below the critical flux is an effective approach to avoid severe fouling including removal and irremovable fouling within a given filtration system. Field et al., (1995) Introduced critical flux concept, operation below the critical flux concept is called sub-critical flux or nonfouling operation and is expected to lead to little irremovable fouling. For a short-term membranes filtration, when the permeate flux is set below the critical flux, the TMP remains stable and fouling was removable. In contrast, when it exceeds the critical flux, the TMP increases and might lead to a TMP jump. As a matter of fact, for a long-term operation of Membrane bioreactors, irremovable fouling can occur even if they are operated below the critical flux. Ognier et al., (2004) reported that despite the initial choice of sub-critical flux filtration conditions, gradual fouling was seen to develop which, after long periods of operation without intermediary membranes regeneration, proved to be hydraulically irremovable. The critical flux value depends on membrane characteristics, operating conditions (i.e., aeration intensity, temperature), and sludge characteristics.

Further discussion of critical flux can be found in recent review articles [29]. However, most of the investigations on the determination of critical flux are based on exsitu measuring, which cannot offer the real fouling propensity. Huyskens et al., (2008) developed an on-line measuring method, which was used to evaluate the removable and irremovable fouling propensity of MBR mixed liquor in a reproducible way. These studies imply that it is possible to develop on- line or in situ method to determine critical flux or removable/irremovable fouling. It is also of high interest to develop a unified measuring method or apparatus.

\section{Biofouling}

From the viewpoint of fouling components, the fouling in Membrane Bioreactors can be classified into three major categories: biofouling, organic fouling, and inorganic fouling. A fundamental understanding of the formation of membrane foulants will help to propose more effective approaches for fouling control. Biofouling refers to the deposition, growth, and metabolism of bacterial cells or flocs on the membranes, which has aroused a significant concern in membrane filtration processes [31, 32]. For low-pressure membranes such as microfiltration and ultrafiltration for treating wastewater, biofouling is a major problem because most foulants (microbial flocks) in Membrane Bioreactors are much larger than the membrane pore size. Biofouling may start with the deposition of an individual cell or cell cluster on the membranes surface, after which the cells multiply and form a bio-cake. Many researchers suggest that SMP and EPS secreted by bacteria also play important roles in the formation of biological foulant and cake layer on membranes surfaces [33, 34]. The deposition of bacterial cells can be visualized by techniques such as Scanning Electron Microscopy (SEM), CLSM, Atomic Force Microscopy (AFM), and Direct Observation through the Membranes (DOTM). The images showed that the flocs could move across the membranes surface by rolling and sliding. Yun et al., (2006) characterized the biofilm structure and analyzed its effect on membranes permeability in MBR for dye wastewater treatment. They found that membranes filterability was closely associated with the structural parameters of the biofilms (i.e., 
porosity, bio-volume). The visualization of biofouling using these techniques is helpful for the understanding of the floc/cell deposition process and the microstructure or architecture of the cake layer.

\section{Organic fouling}

Organic fouling in Membrane bioreactors refers to the deposition of biopolymers (i.e., proteins and polysaccharides) on the membranes. Due to the small size, the biopolymers can be deposited onto the membranes more readily due to the permeate flow, but they have lower back transport velocity due to lift forces in comparison to large particles (e.g., colloids and sludge flocs). Recently, in order to provide a unique insight into the composition (protein and carbohydrate), Metzger et al., (2007) have performed a more detailed study to characterize deposited biopolymers in Membrane Bioreactors. After membranes filtration, the fouling layers were fractionated into the upper layer, an intermediate layer, and lower layer by using rinsing, backwashing, and chemical cleaning. The results showed that the upper fouling layer was composed of a porous, loosely bound cake layer with a similar composition to the sludge flocs. The intermediate fouling layer was contributed equally by SMP and bacteria aggregates and had a high concentration of polysaccharides. The lower layer, representing the irremovable fouling fraction and predominated by SMP, had a relative higher concentration of bound proteins. In order to figure out the detailed information on the deposited biopolymers, identification of these matters is indispensable. Fourier Transform Infrared (FTIR) Spectroscopy, Solid State 13C-Nuclear Magnetic Resonance (NMR) Spectroscopy and High Performance Size Exclusion Chromatography (HP-SEC) are powerful analytical tools for investigation of the organic fouling.

\section{Inorganic fouling}

In general, membranes fouling in Membrane Bioreactors are mainly governed by biofouling and organic fouling rather than by inorganic fouling, although all of them take place simultaneously during membranes filtration of activated sludge. Up to now, thereby, most of the researchers attributed membrane fouling to the deposition of bacterial cells and biopolymers; the inorganic fouling in Membrane bioreactors has been mentioned by only a few papers. Kang et al., (2002) investigated the filtration characteristics of organic and inorganic membranes in a membranes-coupled anaerobic bioreactor, in which a thick cake layer composed of biomass and Struvite $\left(\mathrm{NH}_{4} \mathrm{MgPO}_{4} \cdot 6 \mathrm{H}_{2} \mathrm{O}\right)$ formed on the membranes, especially on the inorganic membranes. Ognier et al., (2002) pointed out there was severe $\mathrm{CaCO}_{3}$ fouling in a pilot MBR with a ceramic ultrafiltration membrane module. In this study, the synthetic wastewater was prepared with hard tap water (concentrations of $\mathrm{Ca}^{2+}$ and $\mathrm{Mg}^{2+}$ are 120 $\mathrm{mg} / \mathrm{L}$ and $8 \mathrm{mg} / \mathrm{L}$, respectively). They found that the high alkalinity of the activated sludge ( $\mathrm{pH} \mathrm{1/4} \mathrm{8-9)} \mathrm{could} \mathrm{cause} \mathrm{the} \mathrm{precipitation} \mathrm{of}$ $\mathrm{CaCO}_{3}$. The investigations by Kang et al., (2002) and Ognier et al., (2002) suggested that on inorganic membranes inorganic fouling may occur more easily. In general, a cake of inorganic matter can be irremovable due to the cohesive properties. More recently, Wang et al., (2008) observed that the cake layer was formed by organic substances and inorganic elements such as $\mathrm{Mg}, \mathrm{Al}, \mathrm{Fe}, \mathrm{Ca}, \mathrm{Si}$, etc. The organic foulant coupled with the inorganic precipitation enhance the formation of a cake layer. Lyko et al., (2007) found that metal substance was a more significant contributor to membranes fouling than biopolymers. Sometimes, the fouling caused by inorganic scaling is not easy to be eliminated even by chemical cleaning You et al., (2006). 
In this paper, fundamentals of waste water treatment by membranes and advances in waste water treatment with strategies in Membrane Bioreactors are reviewed. One of the most crucial problems facing the world in this century is the provision of clean water with adequate quality from water resources. Given the numerous privileges of membranes such as relatively high selectivity and permeability, low energy consumption, operational simplicity, control, scale-up, and adaptability, as well a satisfactory stability under various conditions, over the years membranes have been the dominant technology in the water treatment industry.

\section{Acknowledgement}

I express deepest sense of gratitude towards Dr. Brajesh Singh, having him by my side encouraging me to accomplish this herculean task. He boosted me to ink this article helped me focusing on scripting future prospects pertaining to due proposition.

\section{References}

1. Bourgeous, Keith N., Jeannie L. Darby, and George Tchobanoglous. "Ultrafiltration of wastewater: effects of particles, mode of operation, and backwash effectiveness." Water research 35.1 (2001): 77-90.

2. Chang, In-Soung, et al., "Membrane fouling in membrane bioreactors for wastewater treatment." Journal of environmental engineering 128.11 (2002): 1018-1029.

3. Van Haandel, Adrianus, and Jeroen Van Der Lubbe. Handbook of biological wastewater treatment. IWA Publishing, 2012.

4. Mutamim, Noor Sabrina Ahmad, et al., "Application of membrane bioreactor technology in treating high strength industrial wastewater: a performance review." Desalination 305 (2012): 1-11.

5. Tan, Jia-Ming, Guanglei Qiu, and YenPeng Ting. "Osmotic membrane bioreactor for municipal wastewater treatment and the effects of silver nanoparticles on system performance. "Journal of Cleaner Production 88 (2015): 146-151.

6. Rodríguez, Francisco A., et al., "Kinetic study and oxygen transfer efficiency evaluation using respirometric methods in a submerged membrane bioreactor using pure oxygen to supply the aerobic conditions." Bioresource technology 102.10 (2011): 6013-6018.

7. M.-L. Pellegrin, J. Aguinaldo, S. Arabi, M.E. Sadler, K. Min, M. Liu, C. Salamon, A.D. Greiner, J. Diamond, R. McCandless, C. Owerdieck, J. Wert, L.P. Padhye, "Membranes Processes", Water Environment Research 85 (2013): 1092-1175.

8. Ozgun, Hale, et al., "A review of anaerobic membrane bioreactors for municipal wastewater treatment: integration options, limitations and expectations." Separation and Purification Technology 118 (2013): 89-104.

9. Giacobbo, A., et al., "Integration of membrane bioreactor and advanced oxidation processes for water recovery in leather industry." Desalination and water treatment 56.7 (2015): 17121721.

10. Marrot, B., et al., "Industrial wastewater treatment in a membrane bioreactor: a review." Environmental progress 23.1 (2004): 59-68.

11. Sutton, Paul M. "Membrane bioreactors for industrial wastewater treatment: Applicability and selection of optimal system configuration." Proceedings of the Water Environment Federation 2006.9 (2006): 3233-3248.

12. Sofia, A., W. J. Ng, and S. L. Ong. "Engineering design approaches for 
minimum fouling in submerged MBR." Desalination 160.1 (2004): 67-74.

13. World Bank Group, Towards Drinking Water Security in India - Lessons from the Field, 2011.

14. Government of India - Department of Atomic Energy, Bhabha Atomic research Centre, Chemical Engineering Group, Desalination Division, Desalination and Water Purification Technologies (Technical Information Document), 2010

15. Avalon Global Research, Water and Waste Water Treatment Opportunity in India - An Overview, 2011

16. D and WR (The International Desalination and Water Reuse Quarterly industry website) 2012, India 'to have 500 desalination plants by 2017' - report, http://www.desalination.biz/news/news _story.asp?id=6364

17. Frost and Sullivan 2013b, Commercial and Residential Point-of-Entry (POE) Water Treatment Systems Market in India - Health and Wellness Mega Trend Would Drive Market Growth.

18. Market Pulse 2013, Trends and Opportunities in the Water Purifiers Market.

19. Frost and Sullivan 2012, Analysis of Indian Water and Wastewater Treatment Equipment Market Increasing Industrialization is predicted to Create Huge Opportunities in India.

20. Eldho, T. I. "INDIAN STANDARDS IN WASTEWATER TREATMENT-AN OVERVIEW." (2014): 9-11.

21. Kamyotra, J. S., and R. M. Bhardwaj. "Municipal wastewater management in India. "India Infrastructure Report (2011): 299-311.

22. Lee, Jungmin, Won-Young Ahn, and Chung-Hak Lee. "Comparison of the filtration characteristics between attached and suspended growth microorganisms in submerged membrane bioreactor. "Water Research 35.10 (2001): 2435-2445.

23. Lee, Jungmin, Won-Young Ahn, and Chung-Hak Lee. "Comparison of the filtration characteristics between attached and suspended growth microorganisms in submerged membrane bioreactor. "Water Research 35.10 (2001): 2435-2445.

24. Ping Chu, Hiu, and Xiao- yan Li. "Membrane fouling in a membrane bioreactor (MBR): sludge cake formation and fouling characteristics." Biotechnology and bioengineering 90.3 (2005): 323-331.

25. Jeison, David, and Jules B. van Lier. "Cake formation and consolidation: main factors governing the applicable flux in anaerobic submerged membrane bioreactors (AnSMBR) treating acidified wastewaters." Separation and Purification Technology 56.1 (2007): 71-78.

26. Di Bella, G. A. E. T. A. N. O., et al., "The role of fouling mechanisms in a membrane bioreactor." Water science and technology 55.8-9 (2007): 455-464.

27. Field, R. W., et al., "Critical flux concept for microfiltration fouling." Journal of Membrane Science 100.3 (1995): 259272.

28. Ognier, S., C. Wisniewski, and A. Grasmick. "Membrane bioreactor fouling in sub-critical filtration conditions: a local critical flux concept." Journal of Membrane Science 229.1 (2004): 171-177.

29. Pollice, Alfieri, et al., "Sub-critical flux fouling in membrane bioreactors-a review of recent literature." Desalination 174.3 (2005): 221-230.

30. Huyskens, C., et al., "A new method for the evaluation of the reversible and irreversible fouling propensity of MBR mixed liquor." Journal of Membrane Science 323.1 (2008): 185-192. 
31. Pang, Chee Meng, et al., "Biofilm formation characteristics of bacterial isolates retrieved from a reverse osmosis membrane." Environmental science and technology 39.19 (2005): 7541-7550.

32. Wang, Sunny, Greg Guillen, and Eric MV Hoek. "Direct observation of microbial adhesion to membranes. "Environmental science and technology 39.17 (2005): 6461-6469.

33. Flemming, H-C., et al., "Biofouling - the Achilles heel of membrane processes." Desalination 113.2 (1997): 215-225.

34. Ramesh, A., D. J. Lee, and J. Y. Lai. "Membrane biofouling by extracellular polymeric substances or soluble microbial products from membrane bioreactor sludge. "Applied microbiology and biotechnology 74.3 (2007): 699-707.

35. Yun, Mi-Ae, et al., "Characterization of biofilm structure and its effect on membrane permeability in MBR for dye wastewater treatment." Water Research 40.1 (2006): 45-52.

36. Metzger, Uli, et al., "Characterisation of polymeric fouling in membrane bioreactors and the effect of different filtration modes." Journal of Membrane Science 301.1 (2007): 180-189.

37. Kang, In-Joong, Seong-Hoon Yoon, and Chung-Hak Lee. "Comparison of the filtration characteristics of organic and inorganic membranes in a membranecoupled anaerobic bioreactor. "Water research 36.7 (2002): 1803-1813.

38. Ognier, S., C. Wisniewski, and A. Grasmick. "Characterisation and modelling of fouling in membrane bioreactors. "Desalination 146.1 (2002): 141-147.

39. Wang, Zhiwei, et al., "Membrane fouling in a submerged membrane bioreactor (MBR) under sub-critical flux operation: membrane foulant and gel layer characterization." Journal of Membrane Science 325.1 (2008): 238244.

40. Lyko, Sven, et al., "Polymeric compounds in activated sludge supernatantcharacterisation and retention mechanisms at a full-scale municipal membrane bioreactor." Water Research 41.17 (2007): 3894-3902.

41. You, H. S., et al., "Behavior of membrane scaling during crossflow filtration in the anaerobic MBR system." Separation science and technology 41.7 (2006): 1265-1278.

42. Yamato, Nobuhiro, et al., "Difference in membrane fouling in membrane bioreactors (MBRs) caused by membrane polymer materials." Journal of Membrane Science 280.1 (2006): 911-919.

43. Zhang, Guojun, et al., "Adsorptive fouling of extracellular polymeric substances with polymeric ultrafiltration membranes." Journal of Membrane Science 309.1 (2008): 28-35.

44. Morgan, Paul W. Condensation polymers: by interfacial and solution methods. Vol. 10.Interscience Publishers, 1965.

45. Nataraj, S. K., K. M. Hosamani, and T. M. Aminabhavi. "Nanofiltration and reverse osmosis thin film composite membrane module for the removal of dye and salts from the simulated mixtures." Desalination 249.1 (2009): 12-17.

46. Harisha, R. S., et al., "Arsenic removal from drinking water using thin film composite nanofiltration membrane." Desalination 252.1 (2010): 75-80.

47. Wang, Kai $\mathrm{Yu}$, and Tai-Shung Chung. "Fabrication of polybenzimidazole (PBI) nanofiltration hollow fiber membranes for removal of chromate. "Journal of Membrane Science 281.1 (2006): 307-315.

48. Kim, In-Chul, Kew-Ho Lee, and Tae- 
Moon Tak. "Preparation and characterization of integrally skinned uncharged polyetherimide asymmetric nanofiltration membrane." Journal of Membrane Science 183.2 (2001): 235247.

49. Schäfer, Andrea Iris, Anthony G. Fane, and Thomas D. Waite. Nanofiltration: principles and applications. Elsevier, 2005.

50. Petersen, Robert J. "Composite reverse osmosis and nanofiltration membranes." Journal of membrane science 83.1 (1993): 81-150.
51. Li, Dan, and Huanting Wang. "Recent developments in reverse osmosis desalination membranes. "Journal of Materials Chemistry 20.22 (2010): 4551-4566.

52. Judd, Simon. "The MBR Book-Principles and Applications of Membrane Bioreactors in Water and Wastewater Treatment Elsevier Ltd." (2006).

53. Knoblock, M. D., et al., "Membrane biological reactor system for treatment of oily wastewaters." Water Environment Research 66.2 (1994): 133-139.

\section{How to cite this article:}

Ashutosh Kumar Pandey, Brijesh Singh, Sudha Upadhyay, Srinath Pandey, Ved Kumar Mishra and Prashant Ankur Jain. 2017. Solution for Sustainable Development for Developing Countries: Waste Water Treatment by Use of Membranes (Review). Int.J.Curr.Microbiol.App.Sci. 6(8): 1212-1228. doi: https://doi.org/10.20546/ijcmas.2017.608.149 